Archaeogaming 



\title{
Games People Dig: Are They Archaeological Experiences, Systems or Arguments?
}

\author{
Erik Malcolm Champion \\ Curtin University
}

\begin{abstract}
One of the many but important dilemmas we may encounter in designing or critiquing games for archaeology (Champion 2015) is determining the why: why we should develop, buy, play, and teach specific games for the above disciplines. For archaeology, I propose there is a further important trifurcation: games aiming to convey an experience of archaeology (Hiriart 2018); games aiming to show how systems, methods, findings, and unknowns interact either to produce that experience; or games revealing what is unknown or debated (how knowledge is established or how knowledge is contested).
\end{abstract}

\section{Keywords}

Definitions, Systems, Prototyping, Heritage

How to cite this book chapter:

Champion, E. M. 2020. Games People Dig: Are They Archaeological Experiences, Systems or Arguments? In: Hageneuer, S. (ed.) Communicating the Past in the Digital Age: Proceedings of the International Conference on Digital Methods in Teaching and Learning in Archaeology (12-13 October 2018). Pp. 13-25. London: Ubiquity Press. DOI: https://doi.org/10.5334/bch.b. License: CC-BY 4.0 


\section{Introduction}

Why should we develop, buy, play and teach serious games? If there are insufficient engaging archaeological games, is the problem a lack of photo-realism? Recently, philosophers (Thompson 2016) have accused VR of being parasitic and incapable of simulating the real-world experience but this misses a key value of VR: it can also provide us with explorations of process and predictions. It can act not only as a model of the real world but as an investigation into the processes and interpretations of the real and historic world. For what is visualisation? The London Charter (Denard 2009) defined computer-based visualisation as ' $[t]$ he process of representing information visually with the aid of computer technologies. This implies that visualisation is only visual, that all is required is to represent (in a visual format) content to an end user. It does not explain the cultural significance of the object or process simulated, or reasons for why it should be preserved and communicated. I suggest that cultural learning is a wonderful opportunity for digital archaeology, to explore how different interpretations and world views can be presented and explored.

Digital games, game levels and game mods (modified games) are often easy to change, with simpler development than many CADD systems; it is easy to find students and involve them; and games typically require less maintenance than many expensive VR systems. They have online forums and active modding communities, and inbuilt performance evaluation, and the interaction is typically more intuitive and offers different ways of learning.

Games can help us learn how to:

- manage resources;

- observe and interact with appropriate social behaviour (chat, observation, mimicry);

- visualise or even predict changes in scale, landscape or climate;

- make decisions based on varying levels of uncertainty or probability;

- filter, reconfigure, reconstruct elements of time periods;

- immerse ourselves in the excitement of the times (seen as important to the inhabitants);

- select correct objects or appearance to move about the 'world' or to trade or to advance social role or period of time;

- decipher codes, language, avoid traps;

- follow online or inworld walkthroughs by teachers or inhabitants or students;

- create embedded collaborative storytelling (via film-making or via role-playing, see (Figure 1)).

However, games are based on fast-moving technology. As commercial products they sometimes offer less coding flexibility, they are often looked down upon by academics, they may not offer as much flexibility in transferring content and providing open formats as other software, they have no professional (modding) 


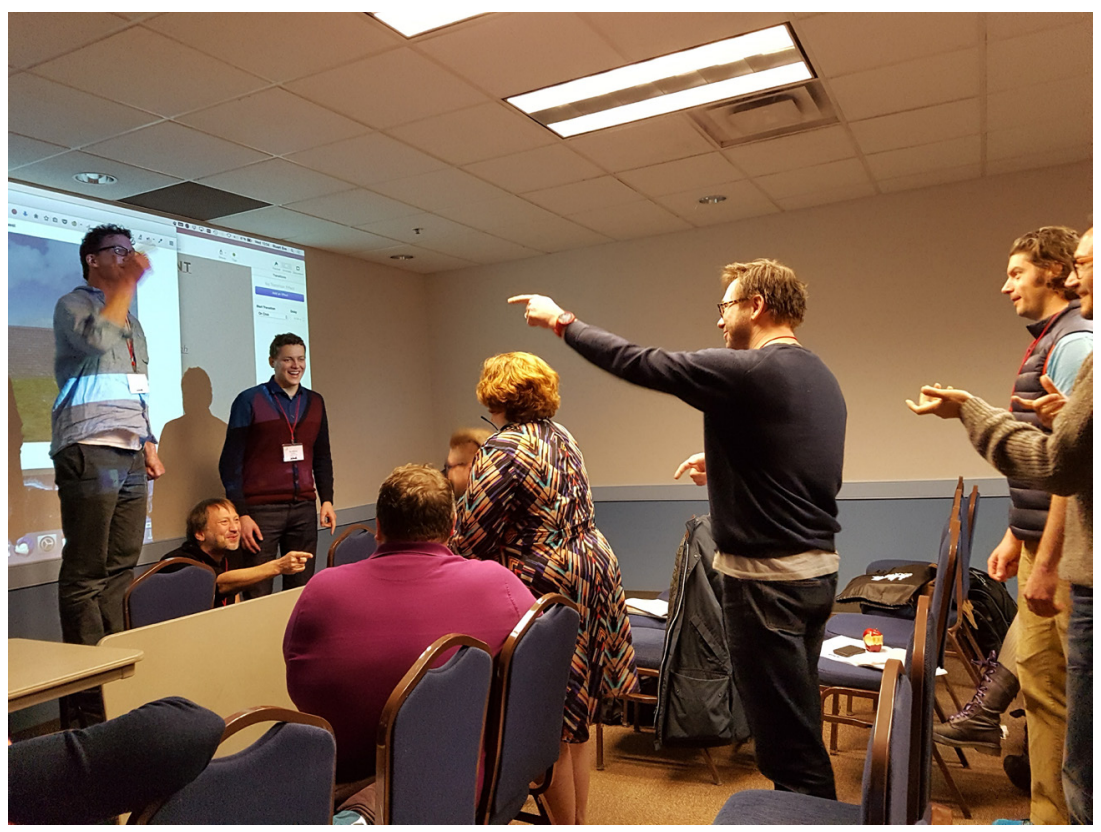

Figure 1: Archaeologists roleplay soldiers marching on each other in Dr Stuart Eve's proposed phenomenological Battle of Waterloo game, CAA2017, Atlanta, Georgia.

support (as that is not their main market) and they usually favour ludic immersion and artistic creativity over historical accuracy. They can also feature genre baggage, if you mod a game with historical content, players may only play that game in a mind-set calibrated to a specific commercial game genre and under-value or miss the historical content.

And it is still not clear how computer games can communicate cultural significance, overcome changing technologies and platforms, demonstrate archaeological methods, interpretations and principles, convey simulated inhabitants' viewpoints, link large scholarly or intangible heritage data, or help local communities to convey traditions (although Never Alone is a worthy exception - see Mol et al. 2017).

Most importantly, games are engaging challenges, a point not always made by game theorists. For example, Salen and Zimmerman (2003) defined a game as '[a] system in which players engage in an artificial conflict, defined by rules, that results in a quantifiable outcome'. Juul (2003) defined a game as '[a] rule-based formal system with a variable and quantifiable outcome, where different outcomes are assigned different values, the player exerts effort in order to influence the outcome, the player feels attached to the outcome, and the consequences of the activity are optional and negotiable'. 
With both definitions, where is the engaging challenge? There is an emphasis on conflict (what about Caillois's forms or modalities of mimesis, vertigo, chance?) The definitions discount games that may never have a final outcome (e.g. cricket) and do not emphasise the importance of strategy or the appeal of player agency. Virtual environments have constraints and affordances; games have risks and rewards. What should a digital archaeological game have?

I believe a successful game must have an engaging challenge. I defined a game (Champion 2006) as 'An engaging challenge that offers up the possibility of temporary or permanent tactical resolution without harmful outcomes to the real-world situation of the participant' and I included 'tactical resolution' to emphasise the importance of strategy and options.

This definition arose from my PhD thesis project (2001-2004), which evaluated approximately 80 students in a pilot study of an Internet Explorer browser-based three-dimensional recreation of the Mayan city Palenque in Chiapas, Mexico. The evaluation, in controlled conditions, tested 12 pairs of museum, archaeology and 3D experts, then five pairs of IT experts at the Lonely Planet headquarters in Melbourne. There were three different modes of interactivity: exploration and observation; conversation with simple NPCs (non-playing characters); and activity (for example, moving a trapdoor that led down to the sarcophagus of Lord Pakal in the Temple of Inscriptions).

On completion of each archaeological/heritage level, the participants were teleported through a portal to a more imaginative game-like level based on Mayan mythology or Mayan history (like the ball court and the mythical crack in the earth). Xavier Quijas Yxayotl, a musician with Mayan heritage, graciously provided musical tracks he composed and played on traditional instruments inspired by Palenque, and the music was trigged in relation to events and to location (the music also faded when participants moved away from the tasks).

I evaluated task performance, their ranking of the three environments in terms of what I called specific presence questions comparing the three environments in terms of their interest-value, their perceived sense of Mayan-specific inhabitation, environmental recall (if participants noticed certain aspects of the digital environments), and subjective experience of time passed (Table 1).

In my evaluation (Table 1), I had to carefully define 'challenge' to the participants. Challenge means an engaging challenge or something people want to avoid; successful games are always the former. Games have genre baggage as well, many people see a game and assume they know how to play it, but understanding specific cultural situatedness (and ways of doing things) may be obscured by the already-understood conventions of popular game genres. For example, if I said the levels were games, participants knew exactly what to do and where to go, but if I said the levels were archaeological reconstructions, participants were confused but treated the environment with more care and concentration on the content.

My results also indicated that those who were quickest to complete tasks scored the lowest in terms of memory recall or understanding the implications 
Table 1: Evaluation questions (Palenque thesis project, 2001-2004).

\begin{tabular}{|c|c|c|}
\hline Evaluation & Content & Objective \\
\hline $\begin{array}{c}\text { Task } \\
\text { performance }\end{array}$ & $\begin{array}{c}6 \text { information objects to find } \\
\text { per environment }\end{array}$ & Compare to understanding \\
\hline \multirow{3}{*}{$\begin{array}{c}\text { Cultural } \\
\text { understanding } \\
\text { (multiple choice) }\end{array}$} & $\begin{array}{l}6 \text { multiple-choice questions } \\
\text { on the Temple of Inscriptions }\end{array}$ & $\begin{array}{c}\text { Compare to preference, task } \\
\text { performance and demographics }\end{array}$ \\
\hline & $\begin{array}{l}6 \text { multiple-choice questions } \\
\text { on the Palace }\end{array}$ & \\
\hline & $\begin{array}{l}6 \text { multiple-choice questions } \\
\text { on the Cross Precinct }\end{array}$ & \\
\hline \multirow[t]{6}{*}{$\begin{array}{l}\text { Presence survey } \\
\text { (rank from } 1 \\
\text { to } 7 \text { ) }\end{array}$} & $\begin{array}{c}\text { Which did you find the most } \\
\text { challenging to explore, find } \\
\text { or change things? }\end{array}$ & $\begin{array}{l}\text { Compare to demographics and } \\
\text { task performance. Find personal } \\
\text { preference in answers (A to } \\
\text { D/E). } \\
\text { Rank the } 3 \text { archaeological and } \\
\text { the } 4 \text { imaginative environments } \\
\text { from } 1 \text { for highest (most, } \\
\text { closest), and } 7 \text { for least close }\end{array}$ \\
\hline & $\begin{array}{l}\text { Which was the most } \\
\text { interesting to you? }\end{array}$ & \\
\hline & $\begin{array}{l}\text { Which seemed most } \\
\text { interactive to you? }\end{array}$ & \\
\hline & $\begin{array}{l}\text { Which did you feel most } \\
\text { closely represented the } \\
\text { way Mayans saw their own } \\
\text { world? }\end{array}$ & \\
\hline & $\begin{array}{l}\text { Which most effectively } \\
\text { seemed inhabited by real } \\
\text { people? }\end{array}$ & \\
\hline & $\begin{array}{l}\text { Which felt most like you } \\
\text { were in the presence of } \\
\text { Mayan culture? }\end{array}$ & \\
\hline \multirow{3}{*}{$\begin{array}{l}\text { Environmental } \\
\text { Recall: did you } \\
\text { notice? (multiple } \\
\text { choice) }\end{array}$} & Shadow? & $\begin{array}{l}\text { Compare to demographics, } \\
\text { to task performance and to } \\
\text { understanding }\end{array}$ \\
\hline & Real People? & \\
\hline & $\begin{array}{c}\text { How tall were Mayans } \\
\text { compared to modern western } \\
\text { people? }\end{array}$ & \\
\hline
\end{tabular}




\begin{tabular}{|c|c|c|}
\hline Evaluation & Content & Objective \\
\hline & $\begin{array}{c}\text { How many real or computer } \\
\text { scripted people were in the } \\
\text { site? }\end{array}$ & \\
\hline & $\begin{array}{c}\text { In future, which would you } \\
\text { like such environments for? }\end{array}$ & \\
\hline $\begin{array}{c}\text { Subjective } \\
\text { experience of } \\
\text { time passing } \\
\text { (rate 1-3) }\end{array}$ & $\begin{array}{c}\text { In each environment, did } \\
\text { time pass by quickest? (Write } \\
\text { in descending order of } \\
\text { apparent speed) }\end{array}$ & $\begin{array}{c}\text { Compare to subjective } \\
\text { preference and to demographics }\end{array}$ \\
\hline & $\begin{array}{c}\text { Rank the environments (1 } \\
\text { for fastest to 3 for slowest) } \\
\text { for how slow they seemed to } \\
\text { be for updating the screen }\end{array}$ & \\
\hline
\end{tabular}

of Mayan history. Surprisingly, the technical improvements important to me as a designer (such as dynamic lighting) were not noticed by most of the participants.

More important to me than genre and typology is exploring whether the game appeals to a particular type of experience. Roger Caillois's (1961) Forms of Play (which I prefer to call modalities of play), goes some way to explaining different types or modes or modalities of playful experience and why they engage players (Table 2). Can game genres or games as interaction modes be compared to what is learned? Can a schematic framework show what can be communicated and why the framework should be undertaken? Plus, can there be criteria revealing when the game is useful while avoiding banal gamification (applying badges and simple reward systems to software and interfaces which are simply routine and boring)?

To break down artificial and conventional categories of game genres, I believe that game modalities of experience and game mechanics are critical: appropriate mechanics help create the feel of the gameplay,

My suggestion is that gameplay related thematically to the goals and setting of the game and game mechanics that are both appropriate and imaginative can help designers avoid the trap of boring games and clumsy gamification. To break down artificial and conventional categories of game genres, I believe that game modalities of experience and game mechanics are critical: choosing the appropriate mode of experience for the player, tied to suitable mechanics, help create the immersive and integrated feel of the gameplay; mechanics push the game along via an internal logic to an eventual final game state; they provide the interactional chassis to the experience.

Game mechanics are typically mechanics to progress the player through the game, but they can also be designed to encourage the player to improve and extend their range of skills and judgement), or to progress the player through the game, or bring together one or more apparent story threads in relation 
Table 2: Three of Roger Callois's Four Forms or Modalities of Play.

\begin{tabular}{|c|c|c|c|}
\hline $\begin{array}{c}\text { Challenge } \\
\text { modes }\end{array}$ & $\begin{array}{c}\text { Engages because } \\
\text { you }\end{array}$ & Archaeology & Pros/Cons \\
\hline $\begin{array}{c}\text { Competition } \\
\text { Agon } \\
\text { competition/ } \\
\text { strategy) }\end{array}$ & $\begin{array}{c}\text { Compete against } \\
\text { people, long-term } \\
\text { decision-making }\end{array}$ & $\begin{array}{c}\text { Civilization-"build } \\
\text { an empire" type } \\
\text { games }\end{array}$ & $\begin{array}{c}\text { + Strategic } \\
+ \text { Engaging } \\
- \text { Means to end }\end{array}$ \\
\hline Chance Alea & $\begin{array}{c}\text { Handle } \\
\text { unpredictability, } \\
\text { humour }\end{array}$ & $\begin{array}{c}\text { Could Spore be an } \\
\text { archaeology game? }\end{array}$ & $\begin{array}{c}\text { + Engaging } \\
- \text { No causality }\end{array}$ \\
\hline $\begin{array}{c}\text { Mimicry } \\
\text { Mimesis }\end{array}$ & $\begin{array}{c}\text { Observation, } \\
\text { control and } \\
\text { humour and } \\
\text { role-playing }\end{array}$ & $\begin{array}{c}\text { Maybe if Sims } \\
\text { 4 were used as } \\
\text { anthropological } \\
\text { machinima? }\end{array}$ & $\begin{array}{c}\text { + Builds empathy } \\
+ \text { Engaging } \\
\text { - Difficult for } \\
\text { interfaces }\end{array}$ \\
\hline
\end{tabular}

to gameplay. They can also help persuade players to develop habits through repeated gameplay, and accustom players to see things in certain ways, or they could shock the player into breaking habits and seeing events, objects or experiences in a new light. We could also imagine insight and reversal mechanics: mechanics that disrupt the in-game or real-world expectations and presumptions of the player acquired previously or during the game in order to reveal to them a viewpoint they may have previously taken for granted or a perspective they never noticed before.

I would agree that games do not normally prioritise interaction to help us understand historical situations. History is usually the backstory; it is not a laboratory to explore. However, it can be a laboratory: my $\mathrm{PhD}$ project made use of gamic simulations to retrieve evaluation data about different forms of interaction, but designing games is also a wonderful way of learning about content.

What is the best way of integrating 3D digital models and commercial (and independent) game content into learning for non-archaeology students? The approach I have taken with my students at three different universities has been to design basic game levels and prototypes to explore new ways of interacting with content, but, as I typically taught multimedia students game design, a focus on heritage and history games was not always possible. The students were organised into groups of four; they pitched their game levels, designed prototypes or fully working levels, and evaluated another group's game design. Their evaluation was also part of the final mark. Although I said they were multimedia students, their game levels featured Minoan, Egyptian, Maltese, Mayan, Chinese and Australian archaeological data, and historical content.

We encountered many issues but that was expected, because my goal for them was to explore new ways of interacting with and learning from games, 


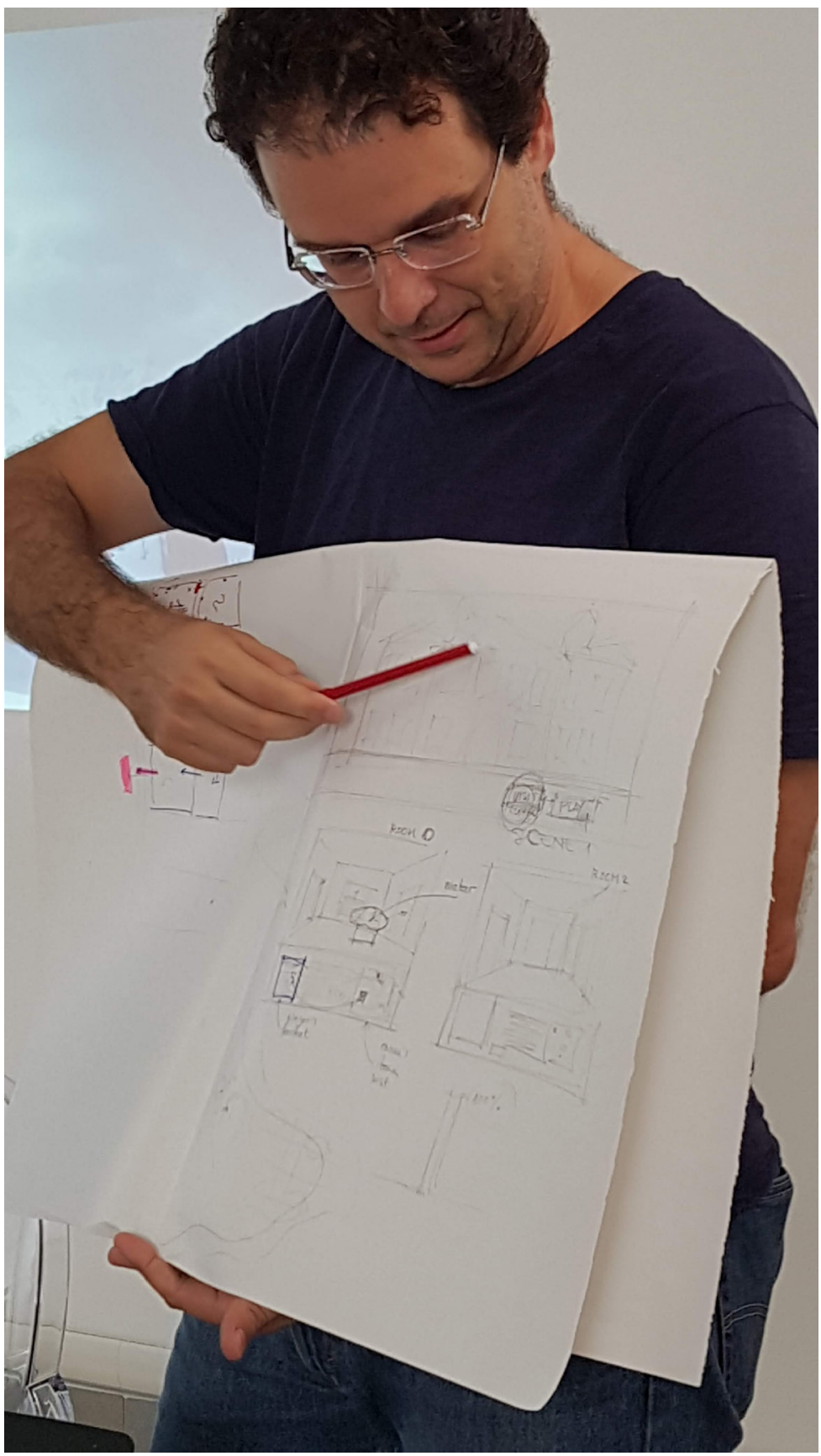

Figure 2: Architect at 2018 Turin Summer School explains a game designed to convey value of artefacts in Brazilian museum fire. 
and to learn from design challenges, not to mimic existing game themes or conventional mechanics. One group built their own game engine from code, a few used the Source game engine, some used Unity, one used Quest3D, but most used Warcraft, Neverwinter Nights or Unreal Tournament. A few built their own Flash games, but most were 3D games or game mods (modified game levels).

Typical problems included how to find suitable interaction metaphors that fitted the context, incorporating game balance, resolving copyright issues as mods, unstable versions (especially in the case of Neverwinter Nights), how to provide learning content but also to afford agency, and the dilemma of whether the gamer should emphasise priority of learning as the primary aim or design the game to be primarily an enjoyable challenge for its own sake.

For prototyping workshops (and I have run game prototyping panels or workshops to archaeologists, historians, and architects at CAA2016 and Turin 2018 Digital Summer School), the problem is simpler.

-What should be experienced and interacted with, as specifically as possible?

-Why are we creating a specific experience in a game? (What are our objectives?)

- Where will the game be played? (What is the background environment, what is the imaginative setting?)

- How do we design prototypes to convey the experience of the site, artefact or model? How can the game prototypes be better designed as systems, methods or findings that interact to produce engaging learning experiences? Or, can the game prototypes reveal what is unknown or debated (how knowledge is established or contested)? Can games be used as interpretative systems or be staged by the player to test or to demonstrate the clash of interpretations or to pose or test a scholarly argument?

-When will the player receive suitable feedback?

To design a game prototype for archaeology, history, or heritage (Figure 3), our first steps are:

1. Determine the cultural, historical, or archaeological facts and interpretations of the site or model that are significant, hidden or otherwise appropriate, engaging or transformative to explore.

2. We must consider the environment it will be played in. This is not just the type of audience but the environment in which they will play the game: together, alone, on a bus, in a lecture theatre, at a museum?

3. To ensure we are designing a game rather than a virtual environment, we need to find a challenge (it could be based on Caillois's modes of game experience or some other theory), and how the core gameplay affects and is affected by the modality of experience. Steps two and three also give us an idea of a setting and theme. 


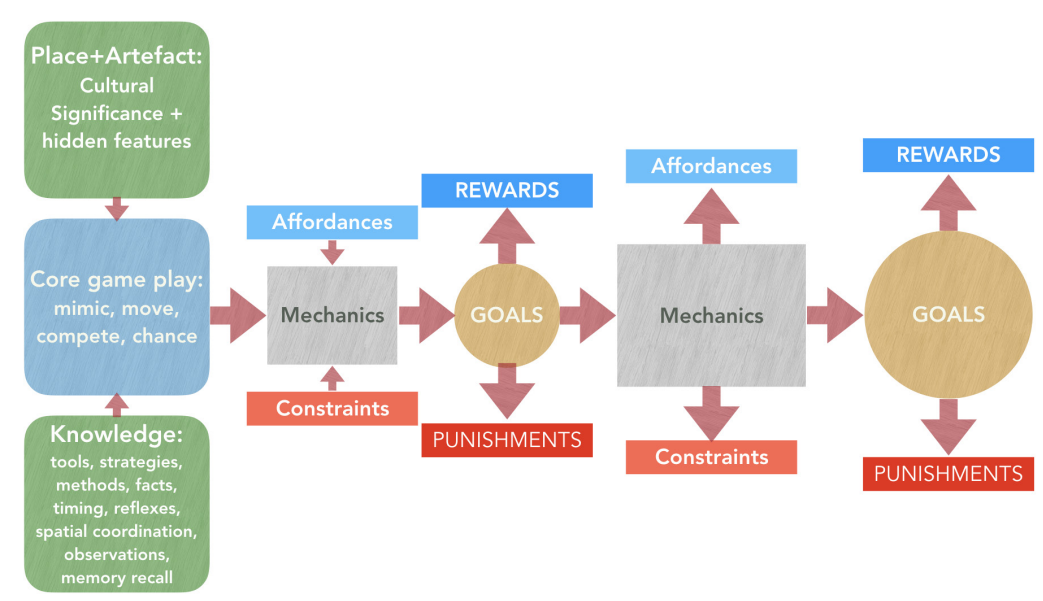

Figure 3: Schematic example of game prototyping components.

4. We need to define the core gameplay. What does the player typically do? Does the game scale, changing in effectiveness and complexity over time? In general, increasing complexity during gameplay keeps players engaged.

5. We also need to develop a reward and punishment system; how do the rewards and punishments interact with the core gameplay and move the game along (i.e. trigger its mechanics)?

6. What is the end state? How will the game mechanics help us get there? Does reaching the end state create an intentional specific reflection, knowledge development, interpretation, experience or other feeling in the player?

\section{Infrastructure}

A further issue we have no space for here, but is of critical importance, is how to maintain and preserve the games, and to include our models, paradata and findings in academic literature. Unfortunately, 3D digital recreations, and by extension games, are not typically considered a key scholarly resource (Di Benedetto et al. 2014), nor is there a great deal of available infrastructure to support them. I hope future projects, and publications like this one, challenge that assumption. One solution is to leverage digital real-time reconfiguration to suit the learner, device and task at hand, in other words personalisation; to increase the sense of agency and therefore personal responsibility; to avail oneself of the opportunities for auto tracking and inbuilt valuation in games; and 
to design a rewards feedback system so that learning is also supported by the game's feedback mechanisms.

I concede that teaching digital heritage and archaeology via existing exemplars is still problematic. Sophisticated but accurate 3D models and related games are hard to find (Tringham \& Ashley 2015), to download and to edit. Accessible models are also typically in unwieldy and obsolete formats and standalone meshes. They seldom have comprehensive metadata or information on how data was acquired or how sharable the content is, or the level of accuracy of scanning or modelling, let alone links to paradata. They also typically do not describe the goals of the model (Champion \& Rahaman 2019).

\section{Summary}

Because of these difficulties I support the development of a scholarly ecosystem: media assets and communities (scholars, shareholders and public) and active participants in game development. I am also heartened by recent development in VR, pushing towards a VR product ecosystem based on consumer level components, phones, head-mounted displays and gaming consoles with additional interface devices.

What is particularly needed, though, is a framework to allow teachers and students to find, relate, annotate and modify existing 3D models and related paradata, and then to comment on them and provide data as to how they could be used for further research and teaching. For example, researchers in Germany have been exploring similar methods to combine metadata, the web and CIDOC CRM to produce Cultural Heritage Markup Language (Hauck \& Kuroczyński 2016), but much more integration work and training needs to be done.

I suggest that, rather than just creating 3D models, we should explore how people would and could use them, with suitable archaeological or historical game mechanics. And, if suitable mechanics do not exist, we should create them! This is why I have suggested simple steps both to leverage the engagement potential of game mechanics and to involve as many people as possible in the design of serious games. For designing games and game prototypes is a meaningful, collaborative activity. Even if the conversations and outputs are not easily conveyed in scholarly articles, they are still important.

\section{References}

Caillois, R. (1961). Man, Play, and Games, Champaign, Illinois: University of Illinois Press.

Champion, E.M. (2006). Evaluating Cultural Learning in Virtual Environments. PhD. University of Melbourne, [pdf] Available at: http://nzerik.googlepages. com/PhDBound-Jan2006.pdf [Accessed 6 May 2019]. 
Champion, E. (2015). Virtual heritage, an introduction. In: G. Robyn and J. Jacobson, eds, The Egyptian Oracle Project; Ancient Ceremony in Augmented Reality, London: Bloomsbury.

Champion, E. and Rahaman, H. (2019). 3D digital heritage models as sustainable scholarly resources. Sustainability, [online] 11(8): 1-8. Available at: http:// www.mdpi.com/2071-1050/11/8/2425 [Accessed 6 May 2019].

Denard, H. (2009). The London Charter for the Computer-Based Visualisation of Cultural Heritage. [online] Available at: http://www.londoncharter.org [Accessed 18 July 2016].

Di Benedetto, M., Ponchio, F., Malomo, L., Callieri, M., Dellepiane, M., Cignoni, P. and Scopigno, R. (2014). Web and mobile visualization for cultural heritage. In: M. Ioannides and E. Quak, eds, 3D Research Challenges in Cultural Heritage: A Roadmap in Digital Heritage Preservation, Berlin and Heidelberg: Springer, pp. 18-35.

Hauck, O. and Kuroczyński, P. 2016. Cultural Heritage Markup Language. In: W. Börner and S. Uhlirz, eds, Proceedings of the 20th International Conference on Cultural Heritage and New Technologies 2015 (CHNT 20, 2015), 2-4 November 2015, Vienna, Austria. Vienna Austria: Museen der Stadt Wien Stadtarchäologie, [pdf] Available at: http://www.chnt.at/wp-content/ uploads/eBook_CHNT20_Hauck_Kuroczynski_2015.pdf [Accessed 6 September 2019].

Hiriart, J.F.V. (2018). The Game of Making an Archaeology Game: Proposing a Design Framework for Historical Game Design. Computer Applications and Quantitative Methods in Archaeology (CAA) International Conference. Tübingen, Germany.

Juul, J. (2003). The game, the player, the world: looking for a heart of gameness. DIGRA Conference-'Level Up', Utrecht, the Netherlands, 4-6 November 2003.

Mol, A.A.A., Ariese-Vandemeulebroucke, C.E., Boom, K.H.J. and Politopoulos, A. (eds) (2017). The Interactive Past: Archaeology, Heritage, and Video Games, Leiden: Sidestone Press.

Salen, K. and Zimmerman, E. (2003). Rules of Play: Game Design Fundamentals, Cambridge, MA: MIT Press.

Thompson, J. (2016). Why Virtual Reality Cannot Match the Real Thing. [online] The Conversation. Available at: https://theconversation.com/why-virtualreality-cannot-match-the-real-thing-92035 [Accessed 6 May 2019].

Tringham, R. and Ashley, M. (2015). Becoming archaeological. Journal of Contemporary Archaeology, 2(1): 29-41.

\section{Ludography}

Warcraft (1994-2018). Blizzard Entertainment. [Multiple platforms]. Neverwinter Nights (2002-2003). BioWare. [Multiple platforms]. 
Unreal Tournament (1999-2020). Epic games. [Multiple platforms].

Civilization series (1991-2016). MicroProse \& Firaxis Games. MicroProse, Activision, Infogrames Entertainment \& $2 \mathrm{~K}$ Games. [Multiple platforms]. Never Alone (Kisima Inyitchuna) (2014). Upper One Games. E-Line Media. [Multiple platforms]. 
